QA: QA

Office of Civilian Radioactive Waste Management

\title{
MONITORED GEOLOGIC REPOSITORY SYSTEMS REQUIREMENTS DOCUMENT
}

$Y M P / C M-0026$

Revision 0

June 2006

U.S. Department of Energy

Office of Civilian Radioactive Waste Management Las Vegas, Nevada 
Preparation:

Dita Trebuls

V. Trebules

Regulatory Authority Office

Approval:

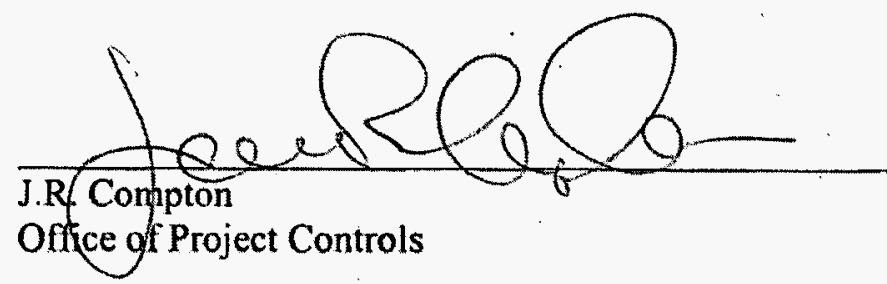

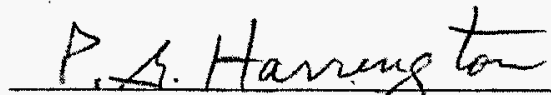
P.G. Harrington, Acting Director Office of the Chief Engineer $\frac{6-2-2006}{\text { Date }}$

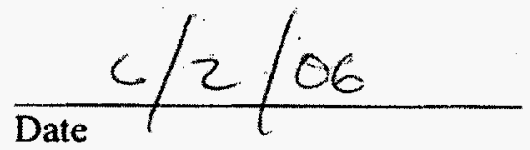

$\frac{6 / 2 / 06}{\text { Date }}$ 


\section{CHANGE HISTORY}

$\begin{array}{lll}\text { Revision } & \text { Interim } & \text { Effective } \\ \text { Number } & \text { Change No. } & \text { Date }\end{array}$

0 .
$0 \quad 06 / 05 / 2006$

\section{Description of Change}

Initial issue. This document will replace Yucca Mountain Site Characterization Project Requirements Document (YMP-RD), YMP/CM-0025, and Repository Design Asset Functional \& Operational Requirements and Design Solutions, DOE/RW-0600. 
INTENTIONALLY LEFT BLANK 


\section{CONTENTS}

Page

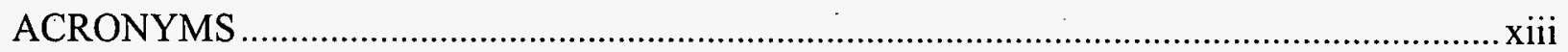

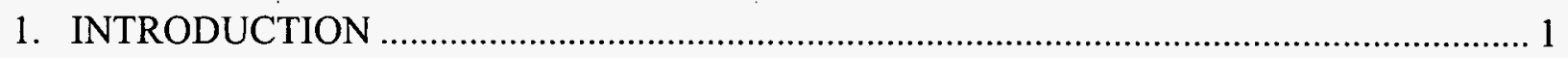

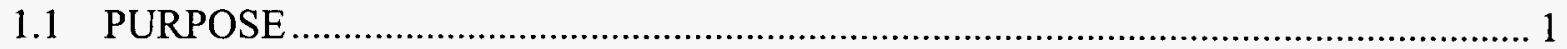

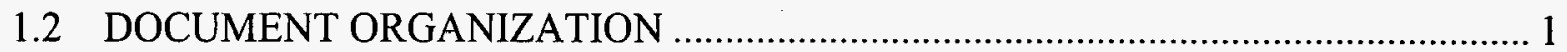

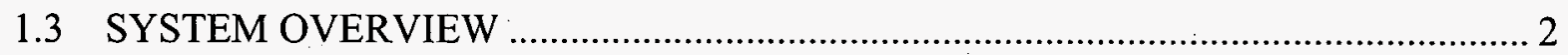

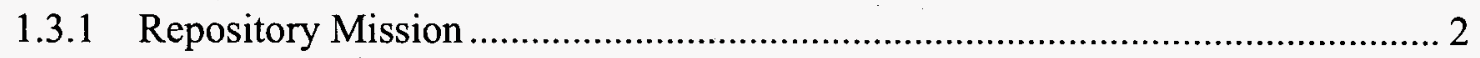

1.3.2 Repository Concept................................................................................ 2

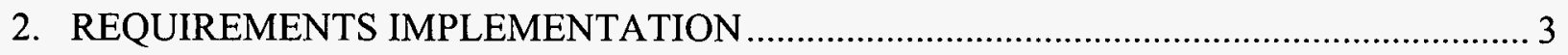

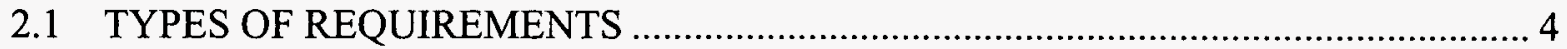

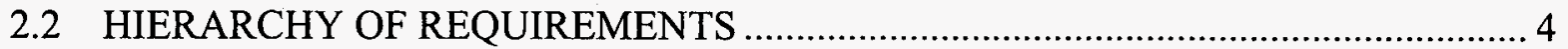

2.3 FOCUS ON TECHNICAL REQUIREMENTS ……............................................. 4

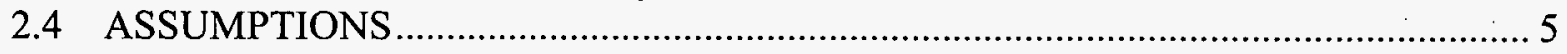

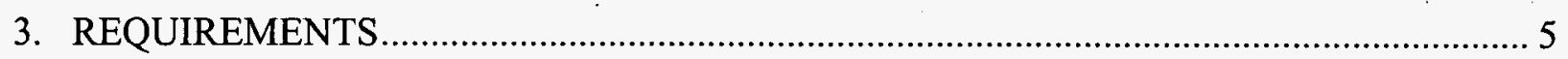

3.1 REPOSITORY SYSTEM-WIDE REQUIREMENTS …....................................... 5

3.1.1 System-Wide Requirements..................................................................... 5

3.1.2 Interface Requirements .......................................................................... 9

3.1.3 Quality Assurance Requirements.................................................................... 9

3.2 ALLOCATION OF REQUIREMENTS TO WORK BREAKDOWN

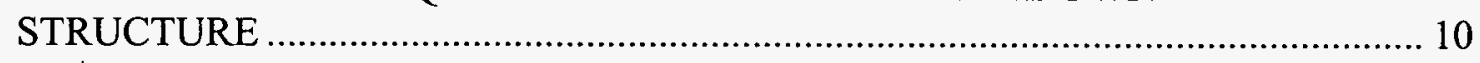

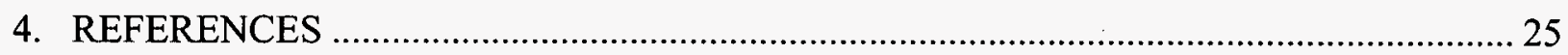

4.2 CODES, STANDARDS, REGULATIONS, AND PROCEDURES ……………….... 27

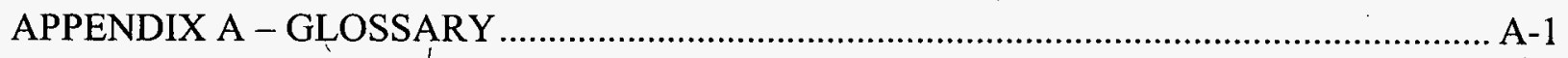

APPENDIX B - TO BE DETERMINED/TO BE VERIFIED LOG............................................

APPENDIX C - MONITORED GEOLOGIC REPOSITORY SYSTEMS REQUIREMENTS DOCUMENT REQUIREMENTS TRACEABILITY TABLES 


\section{INTENTIONALLY LEFT BLANK}




\section{FIGURES}

Page

1. Office of Civilian Radioactive Waste Management Technical Requirements Baseline .......... 1

2. Functional Flow Diagram for the Primary Functions of the Civilian Radioactive Waste Management System. 
INTENTIONALLY LEFT BLANK 


\section{TABLES}

Page

1. Amount of Spent Nuclear Fuel/High-Level Radioactive Waste to Be Accepted in the First Repository (in MTHM or Equivalent). 7 


\section{INTENTIONALLY LEFT BLANK}




\section{ACRONYMS}

CRD Civilian Radioactive Waste Management System Requirements Document

CRWM Civilian Radioactive Waste Management System

DOE U.S. Department of Energy

EM Office of Environmental Management

HLW high-level radioactive waste

IAEA International Atomic Energy Agency

MGR Monitored Geologic Repository

MGR-RD Monitored Geologic Repository Systems Requirements Document

MTHM metric tons of heavy metal

NNPP Naval Nuclear Propulsion Program

NWPA Nuclear Waste Policy Act of 1982

SNF $\quad$ spent nuclear fuel

TSRD Transportation System Requirements Document

WASRD Waste Acceptance System Requirements Document

WBS Work Breakdown Structure

YMP-RD Yucca Mountain Project Requirements Document 
INTENTIONALLY LEFT BLANK 


\section{INTRODUCTION}

\subsection{PURPOSE}

This document establishes the Monitored Geologic Repository system requirements for the U.S. Department of Energy's (DOE's) Civilian Radioactive Waste Management System (CRWMS). These requirements are based on the Civilian Radioactive Waste Management System Requirements Document (CRD) (DOE 2004a). The Monitored Geôlogic Repository. Systems Requirements Document (MGR-RD) is developed in accordance with LP-3.35Q-OCRWM, Preparation, Review, and Approval of Office of Repository Development Requirements Document. As illustrated in Figure 1, the MGR-RD forms part of the DOE Office of Civilian Radioactive Waste Management Technical Requirements Baseline.

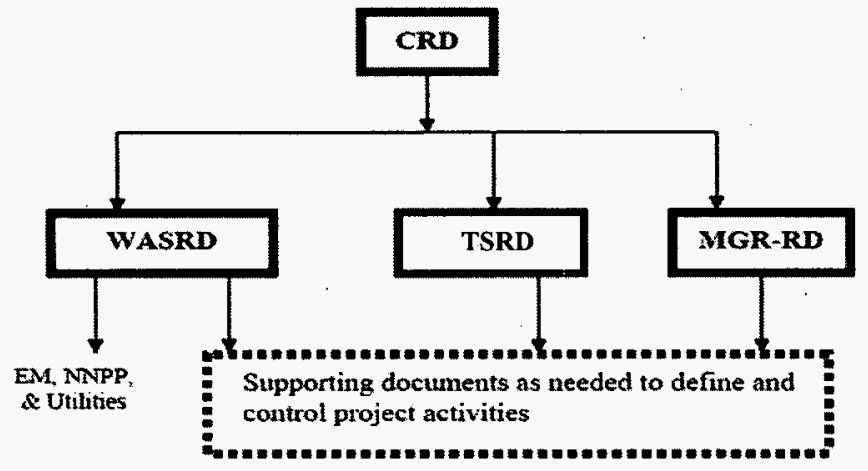

Figure 1. Office of Civilian Radioactive Waste Management Technical Requirements Baseline

Revision 0 of this document identifies requirements for the current phase of repository design that is focused on developing a preliminary design for the repository and will be included in the license application submitted to the U.S. Nuclear Regulatory Commission for a repository at Yucca Mountain in support of receiving a construction authorization and subsequent operating license. As additional information becomes available, more detailed requirements will be identified in subsequent revisions to this document.

\subsection{DOCUMENT ORGANIZATION}

The MGR-RD is organized as follows:

Section 1: Introduction. This section presents an overview of the repository system element, including the mission and system concept.

Section 2: Requirements Implementation. This section identifies the types and hierarchy. of requirements, and assumptions and other factors taken into account to determine what requirements are, or are not, applicable to Monitored Geologic Repository elements.

Section 3: Requirements. This section identifies the CRWMS Yucca Mountain (repository) system element requirements and their allocation to the Work Breakdown Structure (WBS) elements. Requirements that apply to the overall repository system are 
presented, followed by breakouts of the requirements for each element. Interface requirements are also presented.

The appendices include the Glossary; the To Be Determined/To Be Verified Log, and the Monitored Geologic Repository Systems Requirements Document Requirements Traceability Tables.

\subsection{SYSTEM OVERVIEW}

The CRD (DOE 2004a) identifies the repository as an element of the CRWMS. This section defines the repository system in terms of the functions it must perform and the elements that will perform those functions.

Figure 2 shows the functional flow diagram for the primary functions of the CRWMS. Spent nuclear fuel (SNF) and high-level radioactive waste (HLW) are accepted into the CRWMS by the Accept Waste function. This function transfers custody of the waste to the Transport Waste function. The Transport Waste function moves the waste to the Dispose of Waste function.

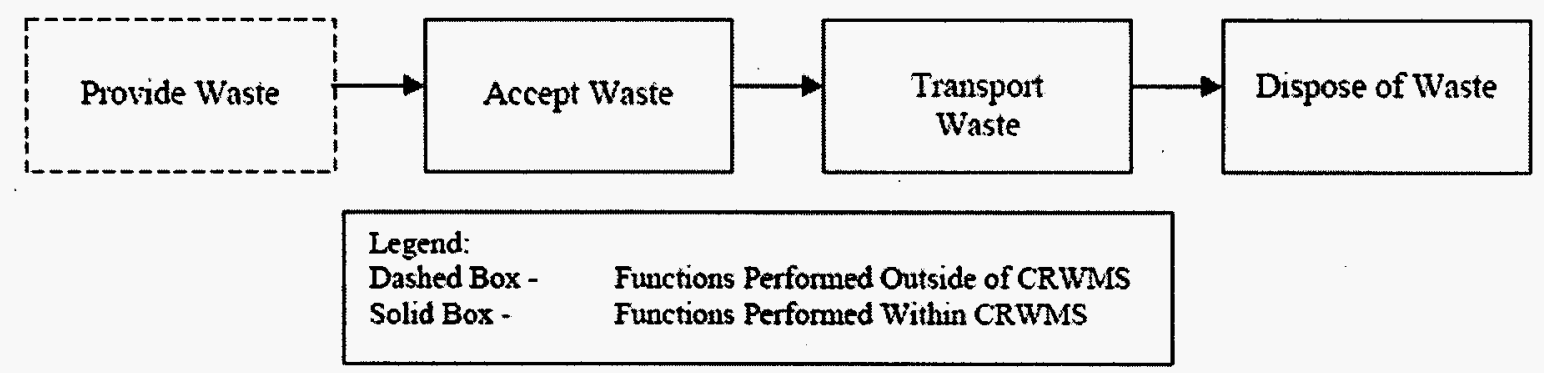

Figure 2. Functional Flow Diagram for the Primary Functions of the Civilian Radioactive Waste Management System

\subsubsection{Repository Mission}

The mission of the repository is to receive and dispose 70,000 metric tons of heavy metal (MTHM) of SNF and HLW at Yucca Mountain. The repository element is to provide the capability and supporting elements to receive; repackage, as necessary; and dispose of 70,000 MTHM SNF and HLW at Yucca Mountain.

\subsubsection{Repository Concept}

The repository is an integral part of the total CRWMS in which all system elements, subsystems, and facilities are described as parts of a single system. The repository will receive transportation casks loaded with SNF and HLW (including vitrified HLW), as well as naval SNF canisters, for handling, transfer, aging, and disposal. 
The repository will be constructed in phases and will include the following elements:

Fuel Handling Facility: The Fuel Handling Facility will receive individual SNF assemblies and canistered fuel in dual-purpose canisters. Waste forms may be loaded either into aging casks or into waste packages for disposal.

Dry Transfer Facility-1\&2: These two facilities will receive all waste forms and transfer same to waste packages or into aging casks.

Canister Handling Facility: The Canister Handling Facility will receive DOE SNF and HLW in canisters, and canistered naval waste. Waste forms may be loaded either into aging casks or into waste packages for disposal.

Aging Pads: The aging pads will provide space for aging (cooling) commercial SNF assemblies that are too hot for emplacement upon receipt at the repository based on the thermal limit for commercial SNF waste packages. Aging can also provide a surge capacity or inventory for additional flexibility in waste disposal operations. Both vertical and horizontal aging is included in the design. Aging pads are constructed of reinforced concrete.

Balance of Plant: The balance of plant area comprises the general infrastructure facilities. The balance of plant area includes: an administration building, a medical center, a fire station, a central warehouse, central shops, a motor pool service station, a visitor center, a utility building, North Portal Entrance Structure, training facility, and security facilities.

Offsite Infrastructure Readiness/Utilities and Roads: These provide increased supply for electrical, water, communications network and roads.

Onsite Infrastructure Readiness/Utilities: Infrastructure readiness and utilities include the roads, water, sewage plant, electrical distribution, and communications network.

Subsurface Facilities: Waste packages will be disposed of in dedicated drifts, and supported on emplacement pallets. The total underground area to accommodate 70,000 MTHM of waste is approximately 1500 acres, with approximately $218,000 \mathrm{ft}$ of excavated emplacement drift. The underground facilities will be excavated over a period of years as the drifts are needed. Non-emplacement excavations in the underground facility include main drifts, exhaust mains, turnouts, performance confirmation test drift, performance confirmation observation drift, alcoves, and ventilation shafts and raises.

\section{REQUIREMENTS IMPLEMENTATION}

This section identifies the types and hierarchy of requirements, assumptions, and other factors taken into consideration in determining what requirements are applicable to the repository elements. 


\subsection{TYPES OF REQUIREMENTS}

Level 2 "technical" requirements are those requirements applicable to the product or service to be delivered. Product requirements are usually listed in specifications or interface control drawings. These are further classified by these requirement types:

- Functional-Qualitative requirements describing what the system needs to do without describing them in quantitative terms. These requirements are usually descriptive and are verified by the summation of the associated performance requirements. An example of a functional requirement is: "The repository shall be designed to dispose of commercial SNF in accordance with the NWPA."

- Performance-Quantitative requirements of system performance, verifiable individually. There are usually several performance requirements associated with a single functional requirement. An example of a performance requirement is: "The repository shall be capable of receiving 400 MTHM of commercial SNF in the initial year of operations."

- Design Constraints-Constraints under which the system is required to operate or exist. Size and weight limitations are included in this category, as are environmental requirements. An example of a design constraint in the area of weight is: "The transporters loaded weight shall not exceed 35 tons."

- Interface-The definition of how the system is required to interact with external systems (external interface), or how subsystems within the system interact with each other (internal interface).

\subsection{HIERA'RCHY OF REQUIREMENTS}

The order of precedence for requirements for this MGR-RD is as follows:

- Federal laws and executive orders

- Requirements of federal agencies and departments (e.g., the DOE, U.S. Nuclear Regulatory Commission, and the U.S. Environmental Protection Agency)

- State laws

- Local ordinances

- National and international standards.

\subsection{FOCUS ON TECHNICAL REQUIREMENTS}

The focus of this document is on technical requirements that drive the design solution. The MGR-RD establishes requirements for the design, construction, and operation of the repository. It specifically addresses the top-level governing laws and regulations (e.g., NWPA; 10 CFR Part 63; and 10 CFR Part 71), along with specific policy, performance requirements, interface 
requirements, and system architecture cited in the CRD (DOE 2004c). The MGR-RD shall be used as a vehicle to incorporate specific changes in technical scope or performance requirements that may have significant project implications. This Project-level document addresses CRD (DOE 2004c) requirements by further defining system elements as described in the WBS and their functions, decomposing requirements into significantly greater detail, and developing designs of system components, facilities, and equipment. Programmatic requirements which do not impact the design of the MGR are not included in this document.

As indicated above, only the top-level governing laws and regulations, as well as DOE directives have been included. The numerous other laws and regulations and DOE directives - those that do not have a direct bearing on the design solution - shall be managed by the terms of the contracts between the DOE and implementing contractors and participants. The specific provisions are commonly incorporated into the contract as clause DEAR 970.5204-2 Laws, Regulations, and DOE Directives.

\subsection{ASSUMPTIONS}

There are currently no assumptions for the MGR-RD, Revision 0.

\section{REQUIREMENTS}

This section identifies the requirements applicable to the repository system element of the CRWMS. Requirements were identified from a variety of source documents such as the CRD (DOE 2004c); federal laws and regulations; DOE orders and directives; interagency and interdepartmental agreements; Office of Civilian Radioactive Waste Management policy and technical decision documents; and consensus standards.

\subsection{REPOSITORY SYSTEM-WIDE REQUIREMENTS}

This section identifies repository system-level requirements, including interface requirements.

A breakout of requirements for each WBS subelement follows. Quality assurance requirements are also provided. Requirements are annotated to show traceability to the source documents on which the requirements are based. Traceability is shown by identifying the source document(s) in square brackets following a statement of the requirement.

\subsubsection{System-Wide Requirements}

3.1.1.A - The MGR shall comply with the applicable provisions of 42 U.S.C.10101 et seq., "The Nuclear Waste Policy Act of 1982" as amended. [CRD 3.1.2.A (DOE 2004c)]

3.1.1.B - The MGR shall comply with the applicable provisions of 10 CFR Part 20, "Standards for Protection Against Radiation." [CRD 3.1.2.B (DOE 2004c)]

3.1.1. $C$ - The MGR shall ensure that commercial SNF and HLW are managed in accordance with 10 CFR Part 961, "Standard Contract for Disposal of Spent Nuclear Fuel and/or High-Level Radioactive Waste." [CRD 3.1.2.C (DOE 2004c)] 
3.1.1.D - The MGR shall comply with all applicable provisions of 10 CFR Part 961, "Standard Contract for Disposal of Spent Nuclear Fuel and/or High-Level Radioactive Waste." [CRD 3.4.A (DOE 2004c)]

3.1.1.E - The MGR shall comply with the applicable provisions of 29 CFR Part 1910, "Occupational Safety and Health Standards." [CRD 3.1.2.D (DOE 2004c)]

3.1.1.F - The MGR shall comply with the applicable provisions of 29 CFR Part 1926, "Safety and Health Regulations for Construction". [CRD 3.1.2.D (DOE 2004c)]

3.1.1.G - The MGR shall comply with applicable provisions of 10 CFR Part 75, "Safeguards on Nuclear Materials-Implementation of U.S./AEA Agreement." [CRD 3.1.2.E (DOE 2004c)]

3.1.1.H - The MGR shall comply with Executive Order 13123 of June 3, 1999, "Greening the Government through Efficient Energy Management" (64 FR 30851). [CRD 3.1.2.G (DOE 2004c)]

3.1.1.I - The MGR shall be designed to dispose of commercial SNF, DOE SNF, vitrified defense HLW, and vitrified commercial HLW, in accordance with the NWPA and implementing regulations. [CRD 3.2.1.A (DOE 2004c)]

3.1.1.J - The MGR shall be capable of receiving SNF and HLW at the annual receipt rates specified in section 3.2.1.B of the CRD, Rev 06. [CRD 3.2.1.B (DOE 2004c)]

3.1.1.K - The MGR shall accept 70,000 MTHM or equivalent of SNF/HLW for disposal in the first repository as authorized by the NWPA, Section 114(d). The allocation, by waste type, is specified in Table 1. [CRD 3.2.1.C (DOE 2004c)]

3.1.1.L - The MGR shall only dispose of SNF or HLW that is not subject to regulation as hazardous waste under the Resource Conservation and Recovery Act of 1976 (RCRA) Subtitle $C$ in the first geologic repository licensed by NRC under the NWPA. [CRD 3.2.1.D (DOE 2004c)]

3.1.1.M - The MGR shall be capable of opening sealed storage/transportable commercial canisters, handling the SNF, and managing associated site generated waste streams.[CRD 3.2.1.F (DOE 2004c)]

3.1.1.N - The MGR facilities shall manage hazardous, nonhazardous, and mixed radioactive wastes in a cost effective manner that meets or exceeds compliance with applicable regulations and protects the health and safety of the public, workers, and the environment consistent with DOE Order O 450.1, Environmental Protection Program. [CRD 3.2.1.I (DOE 2004c)]

3.1.1.O - The MGR structures, systems, and components shall be designed and fabricated in accordance with appropriate industry codes, standards, and engineering principles and practices with particular attention to those which incorporate system safety; human factors, 
reliability, availability, maintainability, habitability standards, and environmental protection. [CRD 3.2.1.J (DOE 2004c)]

Table 1. Amount of Spent Nuclear Fuel/High-Level Radioactive Waste to Be Accepted in the First Repository (in MTHM or Equivalent)

\begin{tabular}{|l|c|}
\hline \multicolumn{1}{|c|}{ Type } & Amount \\
\hline Commercial SNF and HLW & 63,000 \\
\hline Defense HLW & 4,667 \\
\hline DOE and Naval SNF & 2,333 \\
\hline Total & 70,000 \\
\hline
\end{tabular}

3.1.1.P - The MGR shall comply with the requirements of the Nuclear Regulatory Commission (10 CFR Part 63). [CRD 3.4.B. (DOE 2004c)]

3.1.1. $Q$ - The MGR shall comply with the requirements of the Environmental Protection Agency (40 CFR Part 197). [CRD 3.4.B (DOE 2004c)]

3.1.1.R - The MGR shall ensure the physical protection of SNF and HLW received at the repository for disposal in accordance with the safeguards and security requirements in 10 CFR Part 63.21(b)(3). [CRD 3.4.E (DOE 2004c)]

3.1.1.S - The MGR shall ensure the physical protection of SNF and HLW received at the repository for disposal in accordance with the safeguards and security requirements in the applicable material control and accounting provisions of 10 CFR Part 63.78. [CRD 3.4.E (DOE 2004c)]

3.1.1.T - The MGR shall ensure the physical protection of SNF and HLW received at the repository for disposal in accordance with the safeguards and security requirements in the safeguards information protection provisions in 10 CFR Part 73.21. [CRD 3.4.E (DOE 2004c)]

3.1.1.U - The MGR shall ensure the physical protection of SNF and HLW received at the repository for disposal in accordance with the safeguards and security requirements in any applicable interim compensatory measures issued by the NRC. [CRD 3.4.E (DOE 2004c)]

3.1.1. $V$ - The MGR shall have the capability to initiate emplacement in 2010. [CRD 3.4.F (DOE 2004c)]

3.1.1.W - The MGR shall be capable of accommodating a range of storage and transportation technologies, including multipurpose, dual-purpose, and single-purpose canisters, as well as bare SNF assemblies. [CRD 3.2.1.E (DOE 2004c)] 
3.1.1.X - All work to support the LA product, subproducts, and subproduct elements will be performed and completed in accordance with the following direction on the use of data, evaluation of records, and development of documents:

Policy on the Development of Documents That Will be Available to the License Proceeding. [Letter from J. R. Dyer to R. L. Strickler, R. W. Craig, and D. Walker, March 31, 1998 (Dyer 1998a)]

3.1.1.Y - Occupational and public doses of radiation shall be maintained as low as is reasonably achievable (ALARA), per applicable provisions of 10 CFR Part 20. DOE Guide 441.1-2 provides guidance for implementation of ALARA principles. [CRD 3.1.2.B (DOE 2004c)]

3.1.1.Z - SNF and HLW shall be handled in a manner that protects the health and safety of the public and the environment. [10 CFR Part 63]

3.1.1.AA - Low-level radioactive waste generated by repository operations shall be managed in accordance with the requirements of DOE Order 435.1. [DOE O 435.1]

3.1.1.AB - Facilities shall be provided to manage and dispose of repository-generated solid, non-hazardous wastes in compliance with the Solid Waste Disposal Act as implemented in applicable regulations, including 40 CFR Parts 243 and 246. Offsite disposal is acceptable. [40 CFR 243.100(a)] [40 CFR 243.200(d)] [40 CFR 246.100(a) and (b)] [DOE O 450.1]

3.1.1.AC - Units of measure to be used in the design, fabrication, construction, component testing, and operation of procured items for the repository are to be in English units. [Policy Statement, Lake Barrett, September 13, 2001 (Barrett 2001)] Note: All DOE Orders pertaining to metrication, including DOE O 5900.2A, have been withdrawn

3.1.1.AD - The acquisition of capital assets shall be managed as specified in DOE Order 413.3. [DOE O 413.3]

3.1.1.AE - Programs shall be established to ensure that trained and certified equipment operators will be available in sufficient numbers to support start of initial operations. [10 CFR Part 63, Subpart H]

3.1.1.AF - All work to support the LA product, subproducts, and subproduct elements will be performed and completed in accordance with the following direction on the use of data, evaluation of records, and development of documents:

Controlled Use of Scientific and Engineering Data and Models in Support of the YMP LA. [Letter from J. R. Dyer to L. D. Foust, December 5, 1997 (Dyer 1997)] 
3.1.1.AG - All work to support the LA product, subproducts, and subproduct elements will be performed and completed in accordance with the following direction on the use of data, evaluation of records, and development of documents:

Evaluation of Records for Use as References in Project Documents. [Letter from J. R. Dyer to L. D. Foust, January 12, 1998 (Dyer 1998b)]

\subsubsection{Interface Requirements}

3.1.2.A. - Transportation casks, returned by the MGR to the CRWMS Transportation element after removal of their radioactive material shipment must meet the applicable requirements of 10 CFR Part 71, 49 CFR Part 172, and 49 CFR Part 173. [Letter, Arthur to Mitchell, May 5, 2004 (Arthur 2004b)]

3.1.2.B - The MGR design shall comply with the agreements established under the Integrated Interface Control Document (DOE/RW-0511; DOE 2002b) to ensure:

- Compatibility of DOE-owned SNF and HLW waste forms with MGR surface facility interfaces, including canister handling interfaces, and

- Compatibility between transportation equipment (e.g., transporters) and transported items (e.g., casks and canisters) with mechanical and envelop interfaces. [CRD 3.2.1.G (DOE 2004c)]

3.1.2.C - The CRWMS is responsible for the transport of DOE SNF and HLW in casks certified by the NRC. NNPP is responsible for canistering and transporting naval SNF to the repository. [CRD 3.2.1.H (DOE 2004c)]

\subsubsection{Quality Assurance Requirements}

3.1.3.A - The OCRWM Quality Assurance (QA) Program is based on the OCRWM Quality Assurance Requirements and Description document (QARD, DOE/RW-0333P, Revision 16), and applies to the following: A. All structures, systems, and components (SSCs) important to safety or waste isolation, B. Design and characterization of barriers important to waste isolation, and C. Related activities: 1. Performance of the preclosure safety analysis (PCSA), total system performance assessment (TSPA), and their inputs, 2. Characterization related activities (i.e., acquisition, control, and analysis of samples and data), tests and experiments, and scientific studies that provide data to support PCSA, performance confirmation and total system performance assessment, 3. Activities that are important to waste isolation and important to the safety functions of those SSCs (i.e., design, purchasing, fabricating, handling, packaging, shipping, storing, cleaning, erecting, installing, inspecting, testing, maintaining, repairing, and modifying SSCs). [DOE/RW-0333P (DOE 2004b)]

3.1.3.B - All work to support the LA product, subproducts, and subproduct elements will be performed and completed in accordance with the Data, Model, and Code Qualification/Validation and Control Plan prepared by the Civilian Radioactive Waste 
Management System (CRWMS) M\&O and accepted by DOE in December 1998. [Letter from D.R. Wilkins to D.G. Horton, Jan 5, 1999 (Wilkins 1999)]

3.1.3.C - All work to support the LA product, subproducts, and subproduct elements will be performed and completed in accordance with the following direction on the use of data, evaluation of records, and development of documents:

Policy on the Development of Documents That Will be Available to the Licensing Proceedings. [Letter from J.R. Dyer to R.L. Strickler, R.W. Craig, and D. Walker, March 31, 1998 (Dyer 1998a)]

3.1.3.D - Activities and items not subject to the QARD must comply with the requirements of DOE O 414.1C, Quality Assurance. [DOE O 414.1C]

\subsection{ALLOCATION OF REQUIREMENTS TO WORK BREAKDOWN STRUCTURE}

\subsubsection{WBS 1.5.01 PROJECT SUPPORT REQUIREMENTS}

This section defines the technical requirements allocated to project management and other project activities, which are crosscutting throughout the Yucca Mountain Project and cannot be attributed to a specific component of the Project, including the development and integration of project management related policies, procedures, services, and products.

\subsubsection{WBS 1.5.02 LICENSING REQUIREMENTS}

3.2.02.A - Regulatory requirements that must be met by the LA product, subproducts, and subproduct elements include the following:

10 CFR Part 2 Subpart J, Procedures Applicable to Proceedings for the Issuance of Licenses for the Receipt of HLW at a Geologic Repository, which meets the requirements of 36 CFR Part 12 and 44 USC Chapters 21, 29, 31, and 33. [10 CFR 2]

3.2.02.B - The license application shall be developed in accordance with the Nuclear Waste Policy Act of 1982, as amended, and shall be compliant with the requirements of the NRC, as expressed in 10 CFR Part 63, 10 CFR Part 20, 10 CFR Part 2, and other applicable regulations of the NRC. Environmental documentation shall be compliant with the EPA's 40 CFR Part 197. [NWPA 42 USC] [Letter, Hamilton-Ray to Hess, March 12, 2002 (Hamilton-Ray 2002]

3.2.02.C - The license application shall follow the format and content guidance of the NRC's NUREG-1804, Revision 2, Final Report, with the exceptions already allowed in developing the December 2004 draft license application. [Licensing Commitment - Draft LA]

3.2.02.D - The lead-in sections of the license application shall contain non-numbered tables, as did the December 2004 draft license application, that describe where in the section the NRC's applicable acceptance criteria contained in NUREG-1804 are addressed. [Letter, Powers to Mitchell, June 3, 2004 (Powers 2004)] 
3.2.02.E - References contained in the license application shall be specific, including the title, date, revision, and page of the source document, as appropriate, as was done for the December 2004 draft license application. [Letter, Powers to Mitchell, June 3, 2004, item \# 2 (Powers 2004)]

3.2.02.F - All commitments to develop programs or perform specific activities required by 10 CFR 63 made in the license application shall be clearly identified as such and tracked, as was done in the December 2004 draft license application. [Letter, Arthur to Mitchell, July 20, 2004, first bullet (Arthur 2004a)]

3.2.02.G - Design and operational commitments made in the license application shall be identified in the license application and entered into an appropriate commitment tracking system upon submittal of the license application to the NRC. [Letter, Arthur to Mitchell, July 20, 2004, second bullet (Arthur 2004a)]

3.2.02.H - Key assumptions made in the license application with respect to dates and durations of activities in schedules and their completion dates will be shown in the license application. Schedule information should be consistent with other project schedules. [Letter, Arthur to Mitchell, July 20, 2004, third bullet (Arthur 2004a)]

3.2.02.I - Documents or portions of documents incorporated into the license application by reference shall include any limitations on such incorporation such as page numbers, dates of documents, etc., to be scrutable and to minimize the potential for future revisions to sections of the license application incorporating such material. [Letter, Powers to Mitchell, June 3, 2004, item \#3 (Powers 2004)]

3.2.02.J - ICRP 72 is to be used for biokinetic and dosimetric modeling to be performed for public ingestion dose calculations. Worker doses are to be evaluated using ICRP 68 . [Letter, Miller to Walker, December 27, 2004, page 2, paragraph 3 (Miller 2004)]

3.2.02.K - The Regulatory Authority Office submit all parts of the Physical Protection Plan to the NRC no later than six months prior to submittal of the updated license application. [Licensing Commitment - Draft LA]

3.2.02.L - The Regulatory Authority Office shall submit all parts of the Material Control and Accounting Program to the NRC no later than six months prior to submittal of the updated license application. [Licensing Commitment - Draft LA]

3.2.02.M - The Regulatory Authority Office shall submit the Emergency Plan to the NRC no later than six months prior to submittal of the updated license application. [Licensing Commitment - Draft LA]

\subsubsection{WBS 1.5.03 SAFETY ANALYSES AND ASSESSMENT REQUIREMENTS}

3.2.03.A - The postclosure performance assessment, including the total system performance assessment (TSPA), shall be conducted in accordance with 10 CFR 63.113, 10 CFR63.114, 10 CFR 63.115. [10 CFR Part 63] 
3.2.03.B - The content specified in NUREG-1804 shall be followed in so far as is practicable for the safety analysis report (SAR), as was done in the December 2004 draft license application. [Licensing Commitment - Draft LA]

3.2.03.C - SAR Sections 2.3.X, in addition to having a lead-in table discussed in Requirement 3.2.02D, shall have a Summary and Overview subsection following the table that briefly describes how NUREG-1804's acceptance criteria for that section have been met for that section of the SAR. [Letter, Powers to Mitchell, June 3, 2004, item \#1 (Powers 2004)]

\subsubsection{WBS 1.5.04 REPOSITORY FACILITIES (RETIRED)}

\subsubsection{WBS 1.5.05 INITIAL INFRASTRUCTURE READINESS REQUIREMENTS}

Due to the deteriorating condition of some facilities and systems at the Yucca Mountain Project work site, the DOE has determined that selected facilities and systems must be replaced or upgraded in order to provide a safe and healthy workplace to accomplish current mission requirements. The designs for these new or upgraded facilities, infrastructure systems or system components shall meet the following requirements.

3.2.05. $\boldsymbol{A}$ - The fire and rescue service building shall be located at the lower laydown yard. [Letter, Hamilton-Ray to Schlismann, May 24, 2005 (Hamilton-Ray 2005a)]

3.2.05.B - A new modular structure and associated utilities (waste water system and water supply tank) shall be developed at gate 510. [Letter, Hamilton-Ray to Schlismann, September 14, 2005 (Hamilton-Ray 2005b)]

3.2.05. C - Current meteorological monitoring tower and equipment will be relocated. [Letter, Hamilton-Ray to Schlismann, September 14, 2005 (Hamilton-Ray 2005b)]

3.2.05.D - Concrete batch plant shall be capable of ice making and chilling of aggregate. [Letter, Hamilton-Ray to Schlismann, September 14, 2005 (Hamilton-Ray 2005b)]

3.2.05.E - Concrete batch plant shall provide for process calibration to produce precise calibrations. [Letter, Hamilton-Ray to Schlismann, September 14, 2005 (Hamilton-Ray 2005b)]

\subsubsection{Offsite Utilities}

\subsection{Functional Requirements}

The Offsite Facilities shall:

3.2.05.1.1.A - Provide offsite infrastructure to support plant operations. [DOE/RW-0600 Rev 1 (DOE 2003)]

3.2.05.1.1.B - Provide training capability. [DOE/RW-0600 Rev 1 (DOE 2003)] 


\subsection{Design Constraints}

The Offsite Facilities shall:

3.2.05.1.2.A - Provide offsite roads and structures, water, electrical power, and communications to connect to and supply the corresponding onsite utilities. (Government furnished). [DOE/RW-0600 Rev 1 (DOE 2003)]

3.2.05.1.2.B - Provide offsite training capability. [DOE/RW-0600 Rev 1 (DOE 2003)]

\subsubsection{WBS 1.5.06 BALANCE OF PLANT INFRASTRUCTURE REQUIREMENTS}

3.2.06.A - The site layout (plot plan) shall include space for a future shielded canister transfer facility for DPC handing. [DOE/RW-0600 Rev 1 (DOE 2003)]

\subsubsection{Aging System}

\subsection{Functional Requirements}

3.2.06.1.1.A - Facilities and space shall be provided for aging 21,000 MTHM capacity. [BCP-YMP-2004-122/RW, Rev 0 (BSC 2005)]

\subsubsection{Transportation Cask Receipt Return and Waste Package Receipt Building}

\subsection{Functional Requirements}

The Transportation Cask Receipt Return and Waste Package Receipt Building shall:

3.2.06.2.1.A - Receive loaded transportation casks from the Transportation System. [DOE/RW-0600 Rev 1 (DOE 2003)]

3.2.06.2.1.B - Unload transportation casks from the carrier. [DOE/RW-0600 Rev 1.(DOE 2003)]

3.2.06.2.1.C - Load the transportation cask on the surface transporter. [DOE/RW-0600 $\operatorname{Rev} 1$ (DOE 2003)]

3.2.06.2.1.D - Receive unloaded transportation casks from Dry Transfer Facility \#1, Dry Transfer Facility \# 2. [BCP-YMP-2004-013/RW, Rev 0 (BSC 2004a)]

3.2.06.2.1.E - Load the unloaded transportation cask on the carrier and return them to the Transportation System. [DOE/RW-0600 Rev 1 (DOE 2003)]

3.2.06.2.1.F - Receive empty waste package and Engineer Barrier System components. [BCP-YMP-2004-013/RW, Rev 0 (BSC 2004c)]

3.2.06.2.1.G - Prepare empty waste packages. [BCP-YMP-2004-013/RW, Rev 0 (BSC 2004c] 
3.2.06.2.1.H - Load the empty waste packages and associated components on a surface transporter for transfer to Dry Transfer Facilities. [BCP-YMP-2004-013/RW, Rev 0 (BSC 2004c)]

\subsection{Design Constraints}

The Transportation Cask Receipt Return and Waste Package Receipt Building shall:

3.2.06.2.2.A - Provide a minimum of three each parallel lines that can receive and ship rail and truck transportation casks. [DOE/RW-0600 Rev 1 (DOE 2003)]

\subsubsection{Low Level Waste Handling and Removal Function (Site Common Utilities)}

\subsection{Functional Requirements}

The Low Level Waste Handling and Removal Function shall:

3.2.06.3.1.A - Receive low-level radioactive waste generated from the operations of the surface facilities. [DOE/RW-0600 Rev 1 (DOE 2003)]

3.2.06.3.1.B - Package the waste suitable for offsite disposal. [DOE/RW-0600 Rev 1 (DOE 2003)]

\subsubsection{Central Control Center}

\subsection{Functional Requirements}

3.2.06.4.1.A - The Central Control Center Facility shall provide the space, structures, and internal systems that support the Central Operational Control. [BCP-YMP-2004-072/RW, $\operatorname{Rev} 0$ (BSC 2004c)]

3.2.06.4.1.B - The Central Control Center Facility shall provide the space, structures, and internal systems that support the Central Operational Control. [BCP-YMP-2004-072/RW, Rev 0 (BSC 2004c)]

3.2.06.4.1.C - The Central Control Center Facility shall provide the space, structures, and internal systems that support the Central Operational Control. [BCP-YMP-2004-072/RW, Rev 0 (BSC 2004c)]

\subsubsection{Heavy Equipment Maintenance Building}

\subsection{Functional Requirements}

3.2.06.5.1.A - The building shall provide maintenance capability for heavy-load handling equipment. [DOE/RW-0600 Rev 1 (DOE 2003)] 


\subsubsection{Balance of Plant}

\subsection{Functional Requirements}

The MGR shall:

3.2.06.6.1. $A$ - Provide support to the continuous construction operations at the South Portal area, the phased construction activities on the North Portal pad and North Construction Portal, and the continuous waste emplacement operations at the geological repository operations area. [DOE/RW-0600 Rev 1 (DOE 2003)]

3.2.06.6.1.B - Control access for personnel, subsurface emplacement equipment, the waste package transporter, and air flow into the North Portal ramp. [DOE/RW-0600 Rev 1 (DOE 2003)]

\subsubsection{Onsite Infrastructure Development}

\subsection{Functional Requirements}

The Onsite Infrastructure Development shall:

3.2.06.7.1. A - Provide common or site-wide plant operations support. [DOE/RW-0600 Rev 1] (DOE 2003)

3.2.06.7.1.B - Prepare the site for construction and operations. [DOE/RW-0600 Rev 1 (DOE 2003)]

\subsubsection{Onsite Transport}

\subsection{Functional Requirements}

The Onsite Transport shall:

3.2.06.8.1.A - Transport transportation cask carriers to and from the Transportation Cask Receipt Building and the Transportation System Interface. [DOE/RW-0600 Rev 1 (DOE 2003)]

3.2.06.8.1.B - Transport transportation casks between surface facilities. [DOE/RW-0600 Rev 1 (DOE 2003)]

\subsubsection{WBS 1.5.07 SITE OPERATIONS (RETIRED)}

3.2.08 WBS 1.5.08 REPOSITORY PRE-OPERATIONS (RETIRED)

3.2.09 WBS 1.5.09 SPENT NUCLEAR FUEL (RETIRED)

3.2.10 WBS 1.5.10 FINANCIAL AND TECHNICAL ASSISTANCE (RETIRED)

\subsubsection{WBS 1.5.11 OTHER CONTRACTS (SET-ASIDES) (RETIRED)}




\subsubsection{WBS 1.5.12 SUBSURFACE REPOSITORY REQUIREMENTS}

3.2.12.A - The MGR shall be designed to be capable of accommodating emplacement of 70,000 MTHM or equivalent of SNF and HLW, as specified in the Nuclear Waste Policy Act, without precluding the ability to accept additional quantities of nuclear waste up to the projected inventory in the Final Environmental Impact Statement for a Geologic Repository for the Disposal of SNF and HLW at Yucca Mountain, Nye County, Nevada (DOE/EIS-0250). [CRD 3.4.C (DOE 2004c)]

3.2.12.B - For the full range of operating conditions, the MGR shall be designed not to preclude permanent closure for up to 300 years from the start of waste emplacement. [CRD 3.4.D (DOE 2004c)]

\subsubsection{Panel 1}

\subsection{Functional Requirements}

The subsurface repository shall:

3.2.12.1.1.A - Receive waste packages. [BCP-YMP-2004-013/RW, Rev 0 (BSC 2004a]

3.2.12.1.1.B - Conduct performance confirmation activities. [DOE/RW-0600 Rev 1 (DOE 2003)]

3.2.12.1.1.C - Monitor operations and repository performance. [DOE/RW-0600 Rev 1 (DOE 2003)]

3.2.12.1.1.D - Transport completed waste packages from Dry Transfer Facilities to the subsurface for emplacement. [BCP-YMP-2004-013/RW, Rev 0 (DOE 2003)]

3.2.12.1.1.E - Transport waste package in emplacement drift. [DOE/RW-0600 Rev 1 (DOE 2003)]

\subsection{Operational Requirements}

The subsurface repository shall allow for:

3.2.12.1.2.A - Concurrent development and waste emplacement. [DOE/RW-0600 Rev 1 (DOE 2003)]

3.2.12.1.2.B - Maintenance of subsurface thermal goals. [DOE/RW-0600 Rev 1 (DOE 2003)]

\subsection{Design Constraints}

Design Constraints shall accommodate:

3.2.12.1.3.A - Subsurface emplacement area footprint consistent with TSPA. (Reference BSC calculation 800-P00-MGR0-00100-000-00B, figure 6). [DOE/RW-0600 Rev 1 (DOE 2003)] 
3.2.12.1.3.B - Maximum wall temperature during the preclosure period is 96 DEG C. [DOE/RW-0600 Rev 1 (DOE 2003)]

3.2.12.1.3. C - Maximum Cladding temperature is 350 DEG C. [DOE/RW-0600 Rev 1 (DOE 2003)]

3.2.12.1.3.D - Emplacement drift spacing - $81 \mathrm{~m}+5 \%$. [DOE/RW-0600 Rev 1 (DOE 2003)]

3.2.12.1.3.E - Emplacement drift diameter $-5.5 \mathrm{~m}+10 \%$. [DOE/RW-0600 Rev 1 (DOE 2003)]

3.2.12.1.3.F - Non-emplacement drifts, shafts, boreholes and ramps - backfilled and sealed during closure phase. [DOE/RW-0600 Rev 1 (DOE 2003)]

3.2.12.1.3.G - Emplacement drift invert - carbon steel frame with granular ballast. [DOE/RW-0600 Rev 1 (DOE 2003)]

3.2.12.1.3.H - Emplacement drift azimuth - 72 degrees. [DOE/RW-0600 Rev 1 (DOE 2003)]

\subsubsection{Panel 2}

\subsection{Functional Requirements}

The subsurface repository shall:

3.2.12.2.1.A - Receive Waste packages. [BCP-YMP-2004-013/RW, Rev 0 (BSC 2004a)]

3.2.12.2.1.B - Conduct performance confirmation activities. [DOE/RW-0600 Rev 1 (DOE 2003)]

3.2.12.2.1.C - Monitor operations and repository performance. [DOE/RW-0600 Rev 1 (DOE 2003)]

\subsubsection{Panel 3}

\subsection{Functional Requirements}

The subsurface repository shall:

3.2.12.3.1. $A$ - Receive Waste packages. [DOE/RW-0600 Rev 1 (DOE 2003)]

3.2.12.3.1.B - Conduct performance confirmation activities. [DOE/RW-0600 Rev 1 (DOE 2003)]

3.2.12.3.1.C - Monitor operations and repository performance. [DOE/RW-0600 Rev 1 (DOE 2003)] 


\subsubsection{Panel 4}

\subsection{Functional Requirements}

The subsurface repository shall:

3.2.12.4.1.A - Receive Waste packages. [DOE/RW-0600 Rev 1 (DOE 2003)]

3.2.12.4.1.B --Conduct performance confirmation activities. [DOE/RW-0600 Rev 1 (DOE 2003)]

3.2.12.4.1. C - Monitor operations and repository performance. [DOE/RW-0600 Rev 1 (DOE 2003)]

\subsubsection{Waste Package Shields}

\subsection{Functional Requirements}

3.2.12.5.1. $A$ - The waste package shields shall protect the waste package after closure against rock fall and seeping water. [DOE/RW-0600 Rev 1 (DOE 2003)]

\subsubsection{WBS 1.5.13 WASTE PACKAGE REQUIREMENTS}

\subsubsection{Waste Packages}

\subsection{Functional Requirements}

3.2.13.1.1. $A$ - Waste packages shall contain the waste during normal and off-normal operations. [DOE/RW-0600 Rev 1 (DOE 2003)]

3.2.13.1.1.B - Waste packages shall isolate waste, provide criticality control, structural strength, and heat transfer during the postclosure period. [DOE/RW-0600 Rev 1 (DOE 2003)]

\subsubsection{Operational Requirements}

3.2.13.1.2. $A$ - The waste package closure system shall seal and inspect the waste package. [DOE/RW-0600 Rev 1 (DOE 2003)]

\subsection{Design Constraints}

Waste packages shall include the following design features:

3.2.13.1.3. $A$ - One WP inner shell closure lid - Stainless Steel Type 316. [DOE/RW-0600 Rev 1 (DOE 2003)]

3.2.13.1.3.B - Two outer barrier closure lids - Alloy 22 (UNS N06022). [DOE/RW-0600 $\operatorname{Rev} 1$ (DOE 2003)] 
3.2.13.1.3.C - Waste package inner container shell - Stainless Steel Type 316. [DOE/RW0600 Rev 1 (DOE 2003)]

3.2.13.1.3.D - Waste package outer container barrier - Alloy 22 (UNS N06022). [DOE/RW-0600 Rev 1 (DOE 2003)]

3.2.13.1.3.E - Maximum capacity commercial SNF - 21 PWR or 44 BWR. [DOE/RW$0600 \operatorname{Rev} 1$ (DOE 2003)]

3.2.13.1.3.F - Maximum capacity co-disposal waste package - (5 DHLW and 1 DOE SNF) or (2 MCO and 2 DHLW). [DOE/RW-0600 Rev 1 (DOE 2003)]

3.2.13.1.3.G - Maximum capacity naval SNF waste package - 1 Naval SNF Canister. [DOE/RW-0600 Rev 1 (DOE 2003)]

3.2.13.1.3.H - Max WP Heat Output - 11.8 kW. [DOE/RW-0600 Rev 1 (DOE 2003)]

\subsubsection{Waste Package Pallets}

\subsection{Functional Requirements}

3.2.13.2.1.A - Waste package pallets shall support the waste package during transport to emplacement and in the emplacement drift (F\&OR 1.1.3-6). [BCP-YMP-2004-013/RW, Rev 0 (BSC 2004a)]

\subsection{Design Constraints}

3.2.13.2.2.A - WP pallets material shall consist of Alloy 22 (UNS N06022) ends, Stainless Steel Type 316 structural members. [DOE/RW-0600 Rev 1 (DOE 2003)]

\subsubsection{WBS 1.5.14 FUEL HANDLING FACILITY REQUIREMENTS}

\section{2:14.1 Functional Requirements}

The Fuel Handling Facility shall:

3.2.14.1.A - Receive transportation casks and empty waste packages shipped by legal weight truck, overweight truck. [BCP-YMP-2004-072/RW, Rev 0 (BSC 2004c)]

3.2.14.1.B - Prepare the transportation casks for unloading. [BCP-YMP-2004-072/RW, Rev 0 (BSC 2004c)]

3.2.14.1.C - Unload waste form from the transportation cask. [BCP-YMP-2004-072/RW, Rev 0 (BSC 2004c)]

3.2.14.1.D - Load the waste form into the waste package via a dry handling process. [BCP-YMP-2004-072/RW, Rev 0 (BSC 2004c)] 
3.2.14.1.E - Provide canister transfer capability to waste package or overpack. [BCPYMP-2004-072/RW, Rev 0 (BSC 2004c)]

3.2.14.1.F - Capability to load and unload MSCs. Transport capability from BFHF to Aging Pad. [BCP-YMP-2004-072/RW, Rev 0 (BSC 2004c)]

3.2.14.1.G - Prepare the empty shipping cask for closure, close the cask and return the cask to the Cask \& Waste Package Receipt Building or directly to the National Transportation System. [BCP-YMP-2004-072/RW, Rev 0 (BSC 2004c)]

3.2.14.1.H - Load the waste package and pallet onto the waste package transporter. [BCPYMP-2004-072/RW, Rev 0 (BSC 2004c)]

\subsubsection{Operational Requirements}

3.2.14.2.A - The Fuel Handling Facility shall be designed such that the facility could be constructed and made operational in 2010. [BCP-YMP-2004-072/RW, Rev 0 (BSC 2004c)]

3.2.14.2.B - The facility shall have the capability at initiation of operations to receive and transfer vertical dual purpose canisters to the aging facility in an MSC. The facility does not have the capability at initiation of operations to receive and process dual purpose canisters containing CSNF to emplacement; this capability may be added at a future date. [BCP-YMP-2004-072/RW, Rev 0 (BSC 2004c)]

\subsubsection{Design Constraints}

3.2.14.3. $A$ - The Fuel Handling Facility shall include only one closure cell. [BCP-YMP2004-072/RW, Rev 0 (BSC 2004c)]

\subsubsection{WBS 1.5.15 CANISTER HANDLING FACILITY REQUIREMENTS}

\subsubsection{Functional Requirements}

The Canister Handling Facility shall:

3.2.15.1.A - Be capable of receiving casks shipped by Legal Weight trucks or Overweight trucks (OWT). In addition, the CHF shall be capable of handling casks that are transferred from LWT/OWT/or railcars to a Site Rail Transfer Cart (SRTC). [BCP-YMP-2004013/RW, Rev 0 (BSC 2004a)]

3.2.15.1.B - Have the ability to receive MGR site-specific Casks (MSCs) and load canisters into the MSCs. [DOE/RW-0600 Rev 1 (DOE 2003)] 
3.2.15.1.C - Transfer the following types of canisters into Waste Packages or into MGR site specific casks (MSCs) as needed:

Defense High Level Waste and DOE SNF Canisters (short and long), Navy (short and long), Vertical Dual Purpose Canisters (DPC) (Note: into MSC only for Aging), MultiPurpose Canisters (MPCs with commercial Fuel) (Note: MPC assumed to be physically within the bounding dimensions of a Navy Canister length (210.63") and NAC-MPCCY- MPC outside diameter 70.64"). [BCP-YMP-2004-070/RW, Rev 0 (BSC 2004b)]

3.2.15.1.D - Transfer the following type of canister only into Waste Packages: MultiCanister Overpack (MCO). [BCP-YMP-2004-070/RW, Rev 0 (BSC 2004b)]

3.2.15.1.E - Provide a WP load out area to allow WP transporter loading with a completed waste package and shipment to the underground. (Use DTF emplacement transporter system design). [BCP-YMP-2004-070/RW, Rev 0 (BSC 2004b)]

3.2.15.1.F - Be capable of loading and unloading MSCs. Transport capability to/from CHF to Aging Pad. [BCP-YMP-2004-070/RW, Rev 0 (BSC 2004b)]

3.2.15.1.G - Transfer Casks and Waste Packages to intra-plant rail and road infrastructure. [BCP-YMP-2004-013/RW, Rev 0 (BSC 2004a)]

3.2.15.1.H - Be designed with two (2) closure cells. [BCP-YMP-2004-070/RW, Rev 0 (BSC 2004b)]

3.2.15.1.I - Be designed to handle off normal transportation casks (without opening and remediation). Off normal transportation casks (failed gas sampling) will be stored on site until remediation capability is available. [BCP-YMP-2004-070/RW, Rev 0 (BSC 2004b)]

3.2.15.1.J - Store damaged unbreached canisters (if encountered) in a transportation cask or MSC until canister/cask remediation capability is available. [BCP-YMP-2004-070/RW, Rev 0 (BSC 2004b)]

\subsubsection{Operational Requirements}

The Canister Handling Facility shall:

3.2.15.2.A - Be designed such that the facility could be constructed and made operational by no later than June 2010. [BCP-YMP-2004-070/RW, Rev 0 (BSC 2004b)]

\subsubsection{Design Constraints}

The Canister Handling Facility shall:

3.2.15.3.A - Have one (1) transfer and two (2) weld stations and have initial capability to weld canistered waste packages. [BCP-YMP-2004-070/RW, Rev 0 (BSC 2004b)] 
3.2.15.3.B - Provide interim staging for up to 10 DOE canisters. [BCP-YMP-2004070/RW, Rev 0 (BSC 2004b)]

\subsubsection{6 - WBS 1.5.16 DRY TRANSFER FACILITY -1 REQUIREMENTS}

\subsubsection{Functional Requirements}

Dry Transfer Facility-1 shall:

3.2.16.1.A - Receive transportation casks and empty waste packages. [DOE/RW-0600 Rev 1 (DOE 2003)]

3.2.16.1.B - Prepare the transportation casks for unloading. [DOE/RW-0600 Rev 1 (DOE 2003)]

3.2.16.1.C - Unload waste form from the transportation cask. [DOE/RW-0600 Rev 1 (DOE 2003)]

3.2.16.1.D - Load the waste form into the waste package. [DOE/RW-0600 Rev 1 (DOE 2003)]

3.2.16.1.E - Provide canister transfer capability to waste package or overpack. [DOE/RW0600 Rev 1 (DOE 2003)]

3.2.16.1.F - Prepare the empty shipping cask for closure, close the cask and return the cask to the Cask \& Waste Package Receipt Building. [BCP-YMP-2004-013/RW, Rev 0 (BSC 2004a)]

3.2.16.1.G - Load the waste package and pallet onto the waste package transporter. [DOE/RW-0600 Rev 1 (DOE 2003)]

3.2.16.1. $\mathrm{H}$ - Transfer casks and waste packages requiring remediation to the Remediation Facilities. [DOE/RW-0600 Rev 1 (DOE 2003)]

\subsection{Remediation Facility Functional Requirements}

The Dry Transfer Facility-1 Remediation Facility shall:

3.2.16.1.1.A - Receive off-normal waste packages, or transportation casks transported from the DTFs, CHF, and the Transportation Cask Receipt Return \& Waste Package Receipt Building. [BCP-YMP-2004-013/RW, Rev 0 (BSC 2004a)]

3.2.16.1.1.B - Transfer the casks, waste packages, and/or canisters into a safe area for unloading. [DOE/RW-0600 Rev 1 (DOE 2003)]

3.2.16.1.1.C - Unload the cask, waste packages, and/or canister. [DOE/RW-0600 Rev 1 (DOE 2003)] 
3.2.16.1.1.D - Prepare empty cask for closure, close the cask and return the cask to the Transportation Cask Receipt Return \& Waste Package Receipt Building. [BCP-YMP2004-013/RW, Rev 0 (BSC 2004a)]

3.2.16.1.1.E - Manage off-normal fuel assemblies. [BCP-YMP-2004-013/RW, Rev 0 (BSC 2004a)]

3.2.16.1.1.F - Dry and transfer commercial spent nuclear fuel into a cask for transportation to a Dry Transfer Facilities or the Aging Facility. [DOE/RW-0600 Rev 1 (DOE 2003)]

\subsubsection{Operational Requirements}

3.2.16.2.A - Dry Transfer Facility-1 shall have the capability to continue transfer operations with a failure in a transfer cell. [DOE/RW-0600 Rev 1 (DOE 2003)]

\subsection{Remediation Facility Operational Requirements}

3.2.16.2.1.A - Dry Transfer Facility-1 Remediation Facility shall have the capability to remediate containers in both the pool and hot cell. [BCP-YMP-2004-013/RW, Rev 0 (BSC 2004a)]

\subsubsection{Design Constraints}

Dry Transfer Facility-1 shall have the following attributes:

3.2.16.3. $A$ - Capability to handle waste receipt by truck or rail. [DOE/RW-0600 Rev 1 (DOE 2003)]

3.2.16.3.B - Minimum staging capacity 48 PWR CSNF assemblies, 72 BWR CSNF assemblies, and 10 DOE waste canisters. [DOE/RW-0600 Rev 1 (DOE 2003)]

\subsection{Remediation Facility Design Constraints}

3.2.16.3.1.A - Dry Transfer Facility-1 Remediation Facility shall have a minimum pool capacity of 48 PWR and 72 BWR CSNF assemblies. [DOE/RW-0600 Rev 1 (DOE 2003)]

\subsubsection{7 - WBS 1.5.17 DRY TRANSFER FACILITY-2 REQUIREMENTS}

\subsubsection{Functional Requirements}

Dry Transfer Facility -2 shall:

3.2.17.1. A - Receive transportation casks and empty waste packages. [DOE/RW-0600 Rev 1 (DOE 2003)]

3.2.17.1.B - Prepare the transportation casks for unloading. [DOE/RW-0600 Rev 1 (DOE 2003)] 
3.2.17.1. $C$ - Unload waste form from the transportation cask and dual-purpose canisters. [DOE/RW-0600 Rev 1 (DOE 2003)]

3.2.17.1.D - Load the waste form into the waste package. [DOE/RW-0600 Rev 1 (DOE 2003)]

3.2.17.1.E - Prepare the shipping cask for closure, close the cask and return the empty cask to the Transportation Cask Receipt Building. [DOE/RW-0600 Rev 1 (DOE 2003)]

3.2.17.1.F - Load Dual-Purpose Canisters (DPC) into alternate over packs, if required. [DOE/RW-0600 Rev 1 (DOE 2003)]

3.2.17.1.G - Load the waste package and pallet onto the waste package transporter. [DOE/RW-0600 Rev 1 (DOE 2003)]

3.2.17.1. $\boldsymbol{H}$ - Transfer casks and waste packages requiring remediation to the Remediation Facilities. [DOE/RW-0600 Rev 1 (DOE 2003)]

\subsection{Remediation Facility Functional Requirements}

The Dry Transfer Facility-2 Remediation Facility shall:

3.2.17.1.1.A - Receive off-normal waste packages, or transportation casks transported from the DTFs, CHF, and the Transportation Cask Receipt Return \& Waste Package Receipt Building. [BCP-YMP-2004-013/RW, Rev 0 (BSC 2004a)]

3.2.17.1.1.B - Transfer the casks, waste packages, and/or canisters into a safe area for unloading. [DOE/RW-0600 Rev 1 (DOE 2003)]

3.2.17.1.1.C - Unload the cask, waste packages, and/or canister. [DOE/RW-0600 Rev 1 (DOE 2003)]

3.2.17.1.1.D - Prepare empty cask for closure, close the cask and return the cask to the Transportation Cask Receipt Return \& Waste Package Receipt Building. [BCP-YMP2004-013/RW, Rev 0 (BSC 2004a)]

3.2.17.1.1.E - Manage off-normal fuel assemblies. [BCP-YMP-2004-013/RW, Rev 0 (DOE 2003)]

3.2.17.1.1.F - Dry and transfer commercial spent nuclear fuel into a cask for transportation to a Dry Transfer Facilities or the Aging Facility. [DOE/RW-0600 Rev 1 (DOE 2003)]

\subsubsection{Operational Requirements}

3.2.17.2.A - Dry Transfer Facility-2 shall have the capability to continue transfer operations with a failure in a transfer cell. [DOE/RW-0600 Rev 1 (DOE 2003)] 


\subsection{Remediation Facility Operational Requirements}

3.2.17.2.1. A - Dry Transfer Facility-2 Remediation Facility shall have the capability to remediate containers in both the pool and hot cell. [BCP-YMP-2004-013/RW, Rev 0 (BSC 2004a)]

\subsubsection{Design Constraints}

Dry Transfer Facility-2 shall have the following attributes:

3.2.17.3.A - Capability to handle waste receipt by truck or rail. [DOE/RW-0600 Rev 1 (DOE 2003)]

3.2.17.3.B - Minimum staging capacity 48 PWR, 72 BWR CSNF assemblies, and 10 DOE waste canisters. [DOE/RW-0600 Rev 1 (DOE 2003)]

3.2.17.3. $C$ - Dual-purpose canisters can be opened and unloaded. [DOE/RW-0600 Rev 1 (DOE 2003)]

\subsection{Remediation Facility Design Constraints}

3.2.17.3.1.A - Dry Transfer Facility-1 Remediation Facility shall have a minimum pool capacity of 48 PWR and 72 BWR CSNF assemblies. [DOE/RW-0600 Rev 1 (DOE 2003)]

\section{REFERENCES}

Arthur, W.J., III. 2004a. "Clarification to Technical Direction Letter Number 04-033 to Bechtel SAIC Company, LLC (BSC), Contract Number DE-AC28-01RW12101, Management of License Application (LA)." Letter from W.J. Arthur, III (DOE/ORD) to J.T. Mitchell (BSC), July 20, 2004. ACC: MOL.20041023.0092.

Arthur, W.J., III 2004b. "Technical Direction to Bechtel SAIC Company, LLC (BSC), Clarifying Cask Return to Service Requirements; Contract Number DE-AC28-01RW12101, TDL No. 04029." Letter from W.J. Arthur, III (DOE/ORD) to J.T. Mitchell, Jr. (BSC), May 5, 2004, 0505041457, OPM\&E:JTG-0962. ACC: MOL.20040622.0242.

Barrett, L.H. 2001. "Units of Measure to be Used in Design, Fabrication, Construction, Component Testing, and Operation of Procured Items for a Repository." Letter from L.H. Barrett (DOE) to S.P. Mellington (DOE), September 13, 2001, MFR:OPE:SPM-1709. ACC:

MOL.20011003.0303.

BSC (Bechtel SAIC Company) 2004a. Schedule Realignment to Match Facilities Design Strategy. BCP-YMP-2004-013/RW. Baseline Change Proposal. Las Vegas, Nevada: Bechtel SAIC Company. ACC: MOV.20040622.0008.

BSC 2004b. Canister Handling Facility Second Closure Cell. Baseline Change Proposal BCPYMP-2004-070. Las Vegas, Nevada: Bechtel SAIC Company. ACC: MOV.20040622.0012. 
BSC 2004c. Addition of a Fuel Handling Facility and Control Center. BCP-YMP-2004072/RW. Baseline Change Proposal. Las Vegas, Nevada: Office of Civilian Radioactive Waste Management. ACC: MOV.20040713.0016.

BSC 2005. Reduce Aging Pad from 40,000 MTHM to 21,000 MTHM. BCP-YMP-2004122/RW. Baseline Change Proposal. Las Vegas, Nevada: Bechtel SAIC Company. ACC: MOL.20050705.0087.

DOE (U.S. Department of Energy) 1995. Transportation System Requirements Document. DOE/RW-0425, Rev. 2, DCN 01. Washington, D.C.: U.S. Department of Energy, Office of Civilian Radioactive Waste Management. ACC: HQO.19951221.0002.

DOE 2002a. Waste Acceptance System Requirements Document. DOE/RW-0351, Rev. 4. Washington, D.C.: U.S. Department of Energy, Office of Civilian Radioactive Waste Management. ACC: MOL.20020326.0056.

DOE 2002b. U.S. Department of Energy Spent Nuclear Fuel and High-Level Radioactive Waste to the Monitored Geologic Repository. Volume 1 of Integrated Interface Control Document. DOE/RW-0511, Rev. 01. Las Vegas, Nevada: U.S. Department of Energy. ACC: MOL.20020614.0342.

DOE 2003. Repository Design Asset Functional \& Operational Requirements and Design Solutions. DOE/RW-0600, Rev. 1. Las Vegas, Nevada: U.S. Department of Energy, Office of Civilian Radioactive Waste Management. ACC: DOC.20040202.0005.

DOE 2004a. Civilian Radioactive Waste Management System Requirements Document. DOE/RW-0406, Rev. 06. Washington, D.C.: U.S. Department of Energy, Office of Civilian Radioactive Waste Management. ACC: DOC.20040929.0001.

DOE 2004b. Quality Assurance Requirements and Description. DOE/RW-0333P, Rev. 16. Washington, D.C.: U.S. Department of Energy, Office of Civilian Radioactive Waste Management. ACC: DOC.20040907.0002.

DOE 2004c. Yucca Mountain Project Conceptual Design Report. TDR-MGR-MD-000014, Rev. 01. Las Vegas, Nevada: U.S. Department of Energy, Office of Repository Development. ACC: DOC.20041109.0005.

Dyer, J.R. 1997. "Controlled Use of Scientific and Engineering Data and Models in Support of the Yucca Mountain Site Characterization Project License Application." Letter from J.R. Dyer (DOE/OCRWM) to L.D. Foust (CRWMS M\&O), December 05, 1997. ACC: MOL.19971215.0817.

Dyer, J.R. 1998a. "Policy on Development of Documents That Will Be Available to the License Proceeding." Letter from J.R. Dyer (DOE/YMSCO) to R.L. Strickler (CRWMS M\&O), R.W. Craig (USGS), D. Walker (Jason Technologies), March 31, 1998, AML:CMN-1205, with enclosures. ACC: MOL.19980715.0089; MOL.19980715.0090; MOL.19971215.0817;; MOL.19980402.0340. 
Dyer, J.R. 1998b. "Evaluation of Records for Use as References in Project Documents." Letter from J.R. Dyer (DOE/YMSCO) to L.D. Foust (CRWMS M\&O), January 12, 1998, AML:AVG0523, with enclosure. ACC: MOL.19980402.0339; MOL.19980402.0340.

Hamilton-Ray, B.V. 2002. "Contracting Officer Authorization for Bechtel SAIC Company LLC (BSC) Revision to the Yucca.Mountain Site Characterization Project Requirements Document (YMP-RD), YMP/CM-0025, Contract Number DE-AC08-01RW12101, LTR No. 02-043." Letter from B.V. Hamilton-Ray (DOE/ORD) to K.G. Hess (BSC),March 12, 2002. ACC: MOL.20020621.0115.

Hamilton-Ray, B.V. 2005a. "Contract Number DE-AC28-01RW12101-Area 25 Fire and Rescue Deployment, Detailed Baseline Change Proposal (BCP)." Letter from B.V. Hamilton-Ray (DOE/ORD) to D.J. Schlismann (BSC), May 24, 2005. ACC: 20050615.0448.

Hamilton-Ray, B.V. 2005b. "Contracting Officer Authorization for Bechtel SAIC Company, LLC (BSC), Contract Number DE-AC28-01RW12101, Development of a Safety upgrade/infrastructure Readiness Baseline Change Proposal (BCP) and Authorization for Early Start; LTR No. 05-023." )." Letter from B.V. Hamilton-Ray (DOE/ORD) to D.J. Schlismann (BSC), September 14, 2005. ACC: MOL.20051101.0188.

Miller, W.B. 2004. "Contracting Officer (CO) Authorization Letter to AGEISS Environmental, Inc. to Update Biokinetic and Dosimetric Models and Provide Cost and Schedule Impact Estimates for the Effort, Contract Number DE-AD28-03RW12199." Letter from W.B. Miller (DOE/ORD) to S.R. Walker (AGEISS Environmental, Inc.), December 27, 2004. ACC: MOL 20050201.0373.

Powers, K.W. 2004. "Technical Direction to Bechtel SAIC Company, LLC (BSC), Contract Number DE-AC28-01RW12101, Information to be Incorporated in Draft License Application (LA) Chapters, TDL No. 04-036." Letter from K.W. Powers (DOE/ORD) to J.T. Mitchell, Jr. (BSC), June 3, 2004. ACC: MOL.20040816.0401.

Wilkins, D.R. 1999. "Transmittal of Level 4 Deliverable, SLTD7FM4, Data, Model and Code Qualification/Validation and Control Plan." Letter from D.R. Wilkins (CRWMS M\&O) to D.G. Horton (DOE/YMSCO), January 5, 1999, LV.NS.RAS.1/99-001, with enclosure. ACC:

MOL.19990806.0198.

YMP (Yucca Mountain Site Characterization Project) 2001. Yucca Mountain Site Characterization Project Requirements Document (YMP-RD). YMP/CM-0025, Rev. 4, DCN 02. Las Vegas, Nevada: Yucca Mountain Site Characterization Office. ACC: MOL.20010322.0491; MOL.20011107.0002.

\subsection{CODES, STANDARDS, REGULATIONS, AND PROCEDURES}

10 CFR 2. 2006. Energy: Rules of Practice for Domestic Licensing Proceedings and Issuance of Orders. Internet Accessible.

10 CFR 20. 2006. Energy: Standards for Protection Against Radiation. Internet Accessible. 
10 CFR 63. 2006. Energy: Disposal of High-Level Radioactive Wastes in a Geologic Repository at Yucca Mountain, Nevada. Internet Accessible.

10 CFR 71. 2006. Energy: Packaging and Transportation of Radioactive Material. Internet Accessible.

10 CFR 73. 2006. Energy: Physical Protection of Plants and Materials. Internet Accessible.

10 CFR 75. 2006. Energy: Safeguards on Nuclear Material--Implementation of US/IAEA Agreement. Internet Accessible.

10 CFŔ 961. Energy: Standard Contract for Disposal of Spent Nuclear Fuel and/or High-Level Radioactive Waste. Internet Accessible.

29 CFR 1910. Occupational Safety and Health Standards. Internet Accessible.

29 CFR 1926. Safety and Health Regulations for Construction. Internet Accessible.

36 CFR 12. 2001. Parks, Forests, and Public Property: National Cemetery Regulations. ACC: MOL.20050411.0312.

40 CFR 243. 2005. Protection of Environment: Guidelines for the Storage and Collection of Residential, Commercial, and Institutional Solid Waste. ACC: MOL.20060125.0049.

40 CFR 246. 2005. Protection of Environment: Source Separation for Materials Recovery Guidelines. ACC: MOL.20060125.0050.

49 CFR 172. 2005. Transportation: Hazardous Materials Table, Special Provisions, Hazardous Materials Communications, Emergency Response Information, and Training Requirements. ACC: MOL.20060116.0145.

49 CFR 173. 2005. Transportation: Shippers--General Requirements for Shipments and Packagings. ACC: MOL.20060116.0146.

40 CFR 197. 2005. Protection of Environment: Public Health and Environmental Radiation Protection Standards for Yucca Mountain, Nevada. ACC: MOL.20051121.0084.

64 FR 30851. Greening the Government through Efficient Energy Management. Executive Order 13123. ACC: MOL.20050420.0201.

67 FR 16490. Yucca Mountain Review Plan, NUREG-1804, Revision 2,; Draft Report for Comment. Internet Accessible.

DOE O 414.1C. Quality Assurance. Washington, D.C.: U.S. Department of Energy. Internet Accessible.

DOE O 435.1. 1999. Radioactive Waste Management. Washington, D.C.: U.S. Department of Energy. ACC: MOL.20050411.0142. 
DOE O 450.1. Change 2. 2005. Environmental Protection Program. Washington, D.C.: U.S. Department of Energy. Readily available.

DOE O 5900.2A. Use of the Metric System of Measurement. Washington, D.C.: U.S. Department of Energy. Readily available.

LP-3.35Q-OCRWM, Rev. 0. ICN 0. Preparation, Review, and Approval of Office of Repository Development Requirements Document. Washington, D.C.: U.S. Department of Energy, Office of Civilian Radioactive Waste Management. ACC: DOC.20060207.0007.

Nuclear Waste Policy Act of 1982. 42 U.S.C. 10101 et seq. Internet Accessible.

Resource Conservation and Recovery Act of 1976. 42 U.S.C. 6901 et seq. Internet Accessible. 
APPENDIX A

GLOSSARY 


\section{APPENDIX A}

\section{GLOSSARY}

This section provides definitions of key terms used in the MGR-RD. Rather than requirements, the purpose of these definitions is to ensure consistency when describing the CRWMS and its requirements.

Architecture-The physical system to be built, found, or selected to perform a function subject to its stated requirements.

Canister-The structure surrounding the waste form (e.g., HLW immobilized in borosilicate glass) that facilitates handling, storage, transportation, and/or disposal. A canister is a metal receptacle with the following purpose (1) for solidified HLW, its purpose is a pour mold and (2) for SNF, it may provide structural support for intact SNF, loose rods, nonfuel components, or confinement of radionuclides.

Cask-A container for shipping or storing SNF and/or canistered HLW that meets all applicable regulatory requirements.

Civilian Radioactive Waste Management System (CRWMS)-The composite of sites, facilities, systems, equipment, materials, information, activities, and personnel required to perform those activities necessary to manage SNF and HLW disposal.

Commercial High-Level Radioactive Waste-HLW, as defined by the NWPA, 42 U.S.C. 10101(12), resulting from reprocessing SNF in a commercial facility.

Commercial Spent Nuclear Fuel-SNF resulting from operation of a commercial nuclear power reactor. Specifically in this document, SNF includes (1) intact, nondefective fuel assemblies; (2) failed fuel assemblies in canisters; (3) fuel assemblies in canisters; (4) consolidated fuel rods in canisters; (5) nonfuel components inserted in pressurized water reactor fuel assemblies, including, but not limited to, control rod assemblies, burnable poison assemblies, thimble plug assemblies, neutron source assemblies, and instrumentation assemblies; (6) fuel channels attached to boiling water reactor fuel assemblies; and (7) nonfuel components and structural parts of assemblies in canisters.

Defense High-Level Radioactive Waste-HLW, as defined by the NWPA, 42 U.S.C. 10101(12), resulting from reprocessing SNF in a defense facility.

Disposal-The emplacement of radioactive wastes in a geologic repository with the intent of leaving it there permanently. (As defined in 10 CFR 63.2.) Disposal means the emplacement of high-level radioactive waste, SNF, or other highly radioactive material in a repository with no foreseeable intent of recovery, whether or not such emplacement permits the recovery of such waste. (As defined in 10 CFR 961.11 and the NWPA, 42 .U.S.C 10101(9).)

Dispose $\boldsymbol{O}$-The sum of the functions performed by the CRWMS to accept, transport, store, emplace, and isolate waste. 
DOE-Owned Spent Nuclear Fuel (DOE SNF)-SNF that is currently managed by DOE, and includes fuel that has been withdrawn from a nuclear reactor following irradiation, the constituent elements of which have not been separated. DOE SNF includes, but is not limited to, production reactor fuel, research reactor fuel, naval fuel, and some fuel from commercial power reactors.

Function-A primary statement of purpose; it defines what a system or subsystem must accomplish to meet the system mission.

Geologic Repository-A system that is intended to be used for, or may be used for, the disposal of radioactive wastes in excavated geologic media. A geologic repository includes the engineered barrier system and the portion of the geologic setting that provides isolation of the radioactive waste. (As defined in 10 CFR 63.2.)

Geologic Repository Operations Area-A high-level radioactive waste facility that is part of a geologic repository, including both surface and subsurface areas, where waste handling activities are conducted. (As defined in 10 CFR 63.2.)

Hazardous Waste-Any solid waste that exhibits certain characteristics, including corrosivity, ignitability, reactivity, or toxicity, or is specifically listed by the Environmental Protection Agency in its regulations under 40 CFR Part 264. U.S. Environmental Protection Agency regulations under 40 CFR Part 261, et seq., implement the statutory provisions of the Resource Conservation and Recovery Act of 1976.

High-Level Radioactive Waste (HLW)-(1) The highly radioactive material resulting from the reprocessing of SNF, including liquid waste produced directly in reprocessing and any solid material derived from such liquid waste that contains fission products in sufficient concentrations; and (2) other highly radioactive material that the U.S. Nuclear Regulatory Commission, consistent with existing law, determines by rule requires permanent isolation.

(Items) Important to Safety (with reference to structures, systems, and components)-Those engineered features of the geologic repository whose function is: (1) To provide reasonable assurance that high-level waste can be received, handled, packaged, stored, emplaced, and retrieved without exceeding the requirements of 10 CFR 63.111(b)(1) for Category 1 event sequences; or (2) To prevent or mitigate Category 2 event sequences that could result in radiological exposures exceeding the values specified in 10 CFR 63.111(b)(2) to any individual located on or beyond any point on the boundary of the site .

(Items) Important to Waste Isolation, (with reference to design of the engineered barrier system and characterization of natural barriers)-Those engineered and natural barriers whose function is to provide a reasonable expectation that high-level waste can be disposed without exceeding the requirements of $10 \mathrm{CFR} 63.113(\mathrm{~b})$ and (c).

Interface Requirement-A requirement that applies to the inputs to, or outputs from, the function; or the physical connection or dependence between architectural items.

Isolation-Inhibiting the transport of radioactive material to: (1) The location of the reasonably maximally exposed individual so that radiological exposures will not exceed the requirements of 
63.113(b); and (2) The accessible environment so that releases of radionuclides into the accessible environment will not exceed the requirements of 63.113(c). (As defined in 10 CFR 63.2.)

Low-level Radioactive Waste - Radioactive material that 1) is not high-level radioactive waste, spent nuclear fuel, or by-product material (as defined in section IIe(2) of the Atomic Energy Act of 1954, (42 U.S.C. 2014(e) (2)); and 2) the NRC, consistent with existing law and in accordance with paragraph (a), classifies as low-level radioactive waste. This would include items that have become contaminated with radioactive material or have become radioactive through exposure to neutron radiation. This waste typically consists of contaminated protective shoe covers and clothing, wiping rags, mops, filters, and equipment and tools.

Metric Tons of Heavy Metal (MTHM)-As used in this document, refers to the quantity of heavy metal as used in NWPA, or equivalent.

Mixed Waste-Any solid waste that is comprised of both hazardous waste and radioactive waste constituents.

Physical System-The CRWMS, consisting of the composite of the sites, and all facilities, systems, equipment, materials, information, activities, and the personnel required to perform those activities comprising the "Dispose of Waste" function.

Repository-Synonymous with geologic repository.

Requirement-A qualitative or quantitative statement of how well a function must be performed.

Spent Nuclear Fuel (SNF)-Fuel that has been withdrawn from a nuclear reactor following irradiation, the constituent elements of which have not been separated by reprocessing. (As defined in the NWPA, 42 U.S.C. 10101(23), and 10 CFR 961.11.)

Structures, Systems, and Components-A general term that means the standard English definition of those individual words. In this document, if and when structures, systems, and components are used in a way that requires any qualification, such as "important to safety" or "important to waste isolation," that qualifier will also be provided.

System Element-Refers to any of the three major systems required to accomplish the functions of the CRWMS. The three system elements are Waste Acceptance, Transportation, and Monitored Geologic Repository. This differs from the "project" that may be initiated by DOE to manage and control development of one or more system elements.

Technical Baseline-A configuration identification document, or set of such documents, that is formally designated and approved at a specific time. Within the CRWMS, technical baseline is composed of, and evolves through, the functional and technical requirements baseline that is presented in the $\mathrm{CRD}$, the design requirements baseline, the final design baseline, and the as-built baseline.

Transportation Cask-A container for shipping SNF and/or HLW that meets all applicable regulatory requirements. 
Waste Acceptance-The system element or organization that manages the Accept Waste function that includes acceptance of SNF and HLW into the CRWMS from the Purchaser/Custodian/Producer of such waste.

Waste Form-The radioactive waste materials and any encapsulating or stabilizing matrix. (As defined in 10 CFR 63.2.) 
APPENDIX B

TO BE DETERMINED/TO BE VERIFIED LOG 


\section{APPENDIX B \\ TO BE DETERMINED/TO BE VERIFIED LOG}

Not applicable. 
INTENTIONALLY LEFT BLANK 


\begin{abstract}
APPENDIX C
MONITORED GEOLOGIC RESPOSITORY SYSTEMS REQUIREMENTS DOCUMENT REQUIREMENTS TRACEABILITY TABLES
\end{abstract}




\section{APPENDIX C}

\section{MONITORED GEOLOGIC RESPOSITORY SYSTEMS REQUIREMENTS DOCUMENT REQUIREMENTS TRACEABILITY TABLES}

\begin{tabular}{|c|c|c|c|}
\hline CRD Revision 06 Section & $\begin{array}{c}\text { CRD Revision } 06 \\
\text { Requirement }\end{array}$ & Comment & $\begin{array}{c}\text { MGR RD Revision } 0 \\
\text { Requirement }\end{array}$ \\
\hline \multirow{9}{*}{ Programmatic Requirements } & 3.1.1.A & Programmatic & \\
\hline & 3.1.1.B & Programmatic & \\
\hline & 3.1.1.C & Programmatic & $\begin{array}{l}\text { 3.1.1.AD } \\
\text { 3.1.3.A }\end{array}$ \\
\hline & 3.1.1.D & Programmatic & . \\
\hline & 3.1.1.E & Programmatic & \\
\hline & 3.1.1.F & Programmatic & . \\
\hline & $3.1 .1 . \mathrm{G}$ & Programmatic & \\
\hline & 3.1.1.H & Programmatic & \\
\hline & 3.1.1.1 & Programmatic & \\
\hline \multirow{7}{*}{$\begin{array}{l}\text { Primary Regulatory } \\
\text { Requirements }\end{array}$} & 3.1.2.A & & $\begin{array}{l}3.1 .1 . \mathrm{A} \\
3.2 .02 \mathrm{~A}\end{array}$ \\
\hline & 3.1.2.B & & $\begin{array}{l}\text { 3.1.1.B } \\
3.1 .1 . Y\end{array}$ \\
\hline & 3.1.2.C & & 3.1.1.C \\
\hline & 3.1.2.D & & $\begin{array}{l}\text { 3.1.1.E } \\
\text { 3.1.1.F }\end{array}$ \\
\hline & 3.1.2.E & & 3.1.1.G \\
\hline & 3.1.2.F & $\begin{array}{l}\text { Incorporated through } \\
\text { CRD 3.4.E }\end{array}$ & \\
\hline & 3.1.2.G & & 3.1.1.H \\
\hline \multirow{10}{*}{ Overall System Performance } & 3.2.1.A & & 3.1.1.I \\
\hline & 3.2.1.B & & $3.1 .1 . \mathrm{J}$ \\
\hline & 3.2.1.C & & 3.1.1.K \\
\hline & 3.2.1.D & & 3.1.1.L \\
\hline & 3.2.1.E & & 3.1.1.W \\
\hline & 3.2.1.F & & 3.1.1.M \\
\hline & 3.2.1.G & & 3.1.2.B \\
\hline & 3.2.1.H & & 3.1.2.C \\
\hline & 3.2.1.I & & $\begin{array}{l}\text { 3.1.1.N } \\
\text { 3.1.1. } \mathrm{AB} \\
\end{array}$ \\
\hline & 3.2.1.J & & 3.1 .1 .0 \\
\hline $\begin{array}{l}\text { Waste Acceptance and } \\
\text { Transportation Elements } \\
\text { Requirements }\end{array}$ & 3.3 & Not Applicable & \\
\hline
\end{tabular}




\begin{tabular}{|c|c|c|c|}
\hline CRD Revision 06 Section & $\begin{array}{c}\text { CRD Revision } 06 \\
\text { Requirement }\end{array}$ & Comment & $\begin{array}{l}\text { MGR-RD Revision } 0 \\
\text { Requirement }\end{array}$ \\
\hline \multirow{6}{*}{ MGR Element Requirements } & 3.4.A & & 3.1.1.D \\
\hline & 3.4.B & & $\begin{array}{l}3.1 .1 . P \\
3.1 .1 . \mathrm{Q} \\
3.1 .1 . \mathrm{Z} \\
3.1 .1 . \mathrm{AE} \\
3.2 .03 . \mathrm{A}\end{array}$ \\
\hline & 3.4.C & & $3.2 .12 . \mathrm{A}$ \\
\hline & 3.4.D & & 3.2.12.B \\
\hline & 3.4.E & & $\begin{array}{l}3.1 .1 . \mathrm{R} \\
3.1 .1 . \mathrm{S} \\
3.1 .1 . \mathrm{T} \\
3.1 .1 . \mathrm{U} \\
\end{array}$ \\
\hline & 3.4.F & & $3.1 .1 . \mathrm{V}$ \\
\hline
\end{tabular}

\begin{tabular}{|c|c|c|}
\hline YMPERD Requilirement Nurmber & MGR=RD Requfirement Number & Basis \\
\hline \multicolumn{3}{|l|}{ Chapter 1 Requirements } \\
\hline 1.3.1.A & & $\begin{array}{l}\text { Replaced by CRD Rev } 6 \text { - CRD } \\
\text { 3.1.2.A }\end{array}$ \\
\hline 1.3.1.B & & $\begin{array}{l}\text { Replaced by CRD Rev } 6 \text { - CRD } \\
\text { 3.1.2.B }\end{array}$ \\
\hline 1.3.1.C & & Replaced by 10 CFR 63 \\
\hline 1.3.1.D & & Replaced by 10 CFR 63 \\
\hline 1.3.1.E & & $\begin{array}{l}\text { Replaced by CRD Rev } 6 \text { - CRD } \\
\text { 3.1.2.D }\end{array}$ \\
\hline 1.3.1.F & & $\begin{array}{l}\text { Replaced by CRD Rev } 6 \text { - CRD } \\
\text { 3.1.2.D }\end{array}$ \\
\hline 1.3.1.G & ' & $\begin{array}{l}\text { Replaced by CRD Rev } 6 \text { - CRD } \\
\text { 3.2.1.J }\end{array}$ \\
\hline 1.3.1.H & & $\begin{array}{l}\text { Replaced by CRD Rev } 6 \text { - CRD } \\
\text { 3.1.2.E }\end{array}$ \\
\hline 1.3.2.A & & Modified by CRD Rev 06 \\
\hline 1.3.2.B.1 & & $\begin{array}{l}\text { Site Recommendation } \\
\text { Requirement }\end{array}$ \\
\hline 1.3.2.B.2 & & Modified by CRD Rev 06 \\
\hline 1.3.2.C & & Modified by CRD Rev 06 \\
\hline 1.3.2.D & & No Requirement \\
\hline 1.3.2.E & & $\begin{array}{l}\text { Replaced by CRD Rev } 6 \text { - CRD } \\
\text { 3.2.1.B }\end{array}$ \\
\hline
\end{tabular}




\begin{tabular}{|c|c|c|}
\hline YMP-RD Requirement Number & MGR-RD Requirement Number & Basis \\
\hline 1.3.2.F & & Replaced by 10 CFR 63 \\
\hline 1.3.2.G & & No Requirement \\
\hline 1.3.2.H & & Modified by CRD Rev 06 \\
\hline 1.3.2.1 & & No Requirement \\
\hline 1.3.2.J & & Replaced in CRD Rev 06 \\
\hline 1.3.2.K-1.3.2.L & & Replaced in CRD Rev 06 \\
\hline 1.3.2.M - 1.3.2. N & & $\begin{array}{l}\text { Replaced in CRD Rev } 06 \text { - } \\
\text { Suggested that this requirement } \\
\text { applies at lower level }\end{array}$ \\
\hline 1.3.2.0 & & No Requirement \\
\hline 1.3.2.P & & Replaced by 10 CFR 63 \\
\hline 1.3.2.Q & & Replaced in CRD Rev 06 \\
\hline 1.3.3.A & & $\begin{array}{l}\text { Replaced by CRD Rev } 6 \text { - CRD } \\
\text { 3.2.1.J }\end{array}$ \\
\hline 1.3.3.B & & $\begin{array}{l}\text { Replaced by CRD Rev } 6 \text { - CRD } \\
\text { 3.2.1.D }\end{array}$ \\
\hline 1.3.3.C & & No. Requirement \\
\hline 1.3.3.D & & $\begin{array}{l}\text { Replaced by CRD Rev } 6 \text { - CRD } \\
\text { 3.2.1.E }\end{array}$ \\
\hline 1.3.3.E & & $\begin{array}{l}\text { Replaced by CRD Rev } 6 \text { - CRD } \\
\text { 3.2.1.F }\end{array}$ \\
\hline 1.3.3.F & & Modified by CRD Rev 06 \\
\hline 1.3.3.G & & Modified by CRD Rev 06 \\
\hline 1.3.3.H & & Replaced in CRD Rev 06 \\
\hline 1.3.3.1 & & Replaced in CRD Rev 06 \\
\hline 1.3.3.J & & Replaced by 10 CFR 63 \\
\hline 1.3.3.K & & Replaced in CRD Rev 06 \\
\hline 1.3.3.L & & Replaced by 10 CFR 63 \\
\hline 1.3.3.M - 1.3.3.R & & Replaced in CRD Rev 06 \\
\hline 1.3 .4 & & Replaced in CRD Rev 06 \\
\hline 1.3.4.1 & & Replaced by 10 CFR 63 \\
\hline 1.3.4.2.A - 1.3.4.3.C & & Replaced in CRD Rev 06 \\
\hline \multicolumn{3}{|l|}{ Chapter 2 Requirements } \\
\hline 2.3.1.01-2.3.2.04.34 & & Replaced by 10 CFR 63 \\
\hline 2.3.2.04.35 & & Replaced by CRD Rev 06 \\
\hline 2.3.2.04.36 & & Replaced by 10 CFR 63 \\
\hline 2.3.2.04.37- 40 & & Modified by CRD Rev 06 \\
\hline 2.3.2.04.41 & & Programmatic \\
\hline 2.3.2.04.42 & & Site Characterization Requirement \\
\hline 2.3.3.03.01-2.3.4.03.03 & & Covered by List B \\
\hline
\end{tabular}




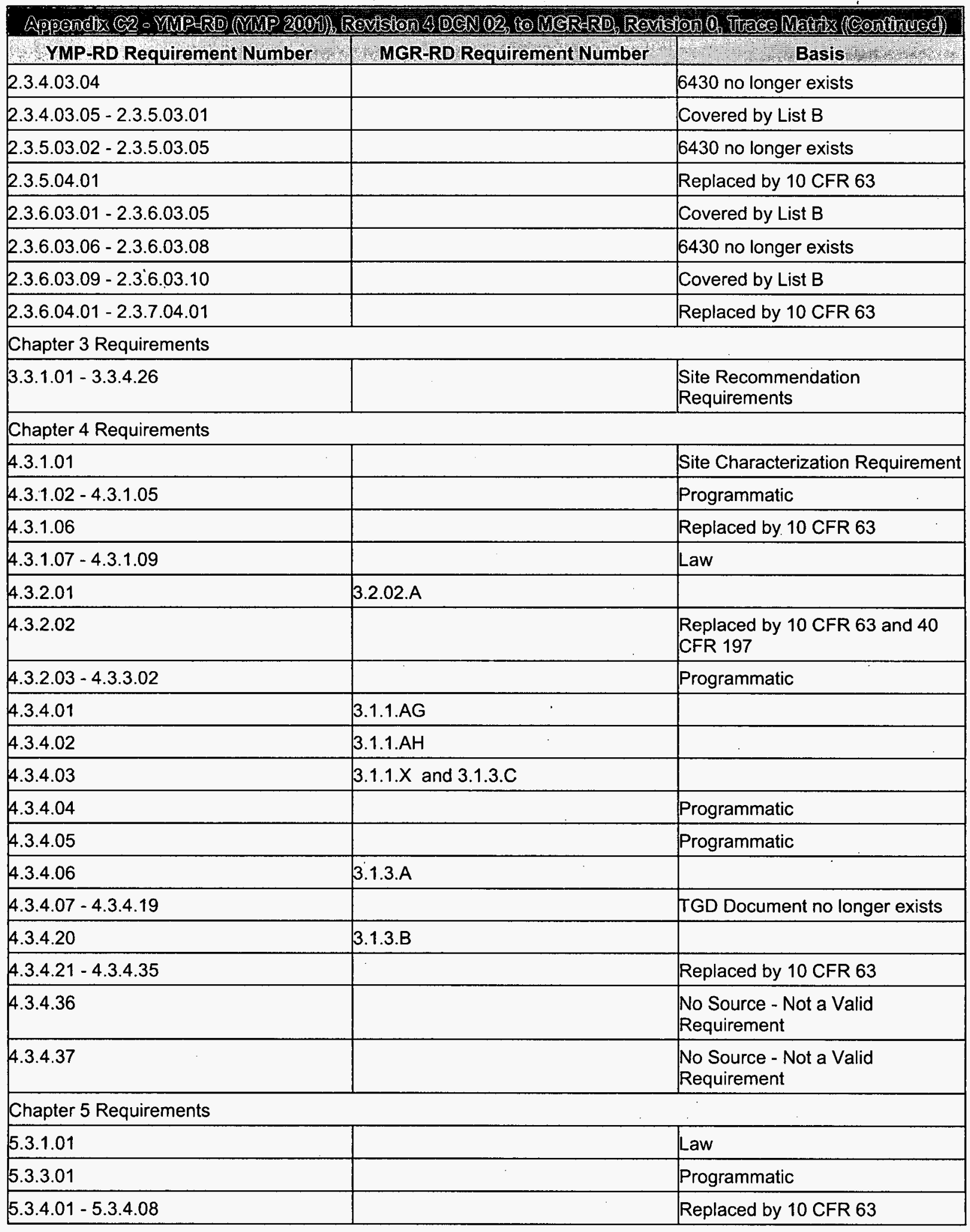




\begin{tabular}{|c|c|c|}
\hline 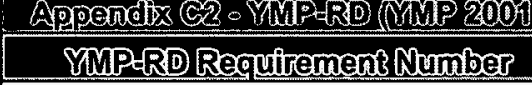 & $\begin{array}{l}\text { Tiston 4 DGN } 02, \text { 20 MGR=RD, ReV } \\
\text { MGR=RD Requitement Number }\end{array}$ & 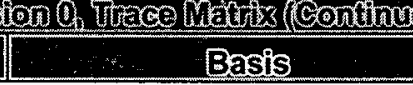 \\
\hline \multicolumn{3}{|l|}{ Chapter 6 Requirements } \\
\hline 6.3 .1 .01 & & Law \\
\hline 6.3 .3 .01 & & Programmatic \\
\hline $6.3 .4 .01-6.3 .4 .04$ & & Replaced by 10 CFR 63 \\
\hline \multicolumn{3}{|l|}{ Chapter 7 Requirements } \\
\hline 7.3.1.01 & & $\begin{array}{l}\text { Redundant with CRD Rev } 06 \\
\text { 3.1.2.A }\end{array}$ \\
\hline 7.3.1.02 - 7.3.4.26 & & Captured in List AlList B \\
\hline
\end{tabular}


INTENTIONALLY LEFT BLANK 